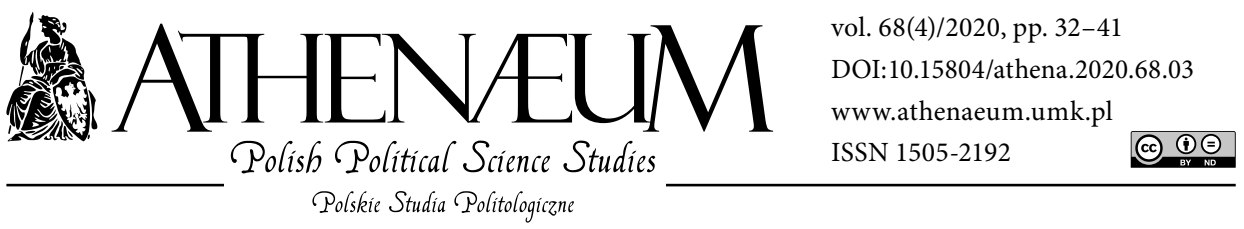

\title{
DISINFORMATION VIRUS: FAKE NEWS IN THE PANDEMIC ERA
}

\author{
WIRUS DEZINFORMACJI. FAKE NEWS W DOBIE PANDEMII
}

Karolina Pałka-Suchojad*

\begin{abstract}
This article describes the issue of misinformation during the SARS CoV-2 pandemic, which WHO called 'infodemic'. The outbreak of the pandemic has changed the constellation of the information environment, where there is a noticeable increase in fake news, conspiracy theories and the hate speech they generate. The modified architecture of digital space causes the formation of new instruments, influence factors, phenomena - previously recognized, but never before so intense.

The article focuses on fake news that appeared in connection with the ongoing pandemic and which is present in Polish public discourse. The adopted perspective allowed to look at the phenomenon of false information through the prism of the theory of information laundering.
\end{abstract}

Keywords: laundering information theory; disinformation; fake news; pandemic; social media
Niniejszy artykuł podejmuje temat dezinformacji w dobie pandemii SARS CoV-2, określany przez WHO nazwą „infodemia”. Wybuch pandemii spowodował zmianę konstelacji środowiska informacyjnego, gdzie zauważalny jest przyrost fake newsów, teorii spiskowych i generowanej przez nie mowy nienawiści. Zmodyfikowana architektura przestrzeni cyfrowej powoduje kształtowanie się nowych instrumentów, czynników wpływu, zjawisk - dotychczas rozpoznanych, lecz nigdy wcześniej tak nasilonych.

Artykuł koncentruje się na fake newsach, które pojawiły się w związku z trwającą pandemią, a które obecne są $\mathrm{w}$ polskim dyskursie publicznym. Przyjęta perspektywa pozwoliła spojrzeć na zjawisko fałszywych informacji przez pryzmat teorii „prania informacji”.

Słowa kluczowe: teoria prania informacji; dezinformacja; fake news; pandemia; media społecznościowe

* Jan Kochanowski University in Kielce, Faculty of Law and Social Sciences. 
We're not just fighting an epidemic; we're fighting an infodemic

Tedros Adhanom Ghebreyesus ${ }^{1}$

Historical outbreaks of pandemic decimated populations, determined the results of wars, but also, paradoxically, opened the way to innovation and scientific and economic progress, redefined political systems, and the ongoing SARS CoV-2 pandemic additionally strongly affects the information sphere. Pandemics also resulted in the stigmatization of a group or nation, assigning responsibility for spreading the virus to it, as was the case with the "Spanish flu", a similar trend can be observed today.

Disinformation campaigns in a pandemic are not a new trend. Historically, disinformation and fake news have accompanied many of them, such as the 1918-1919 "Spanish flu" epidemic. At that time, the German pharmaceutical company Bayer was blamed for the spread of the flu virus, which was to deliberately inject the pathogen into aspirin tablets. Others believed that the disease spread through the air like a chemical weapon. Fear of a pandemic, strong war propaganda and racism were the grounds for this type of disinformation (Cotter, 2020).

The ongoing disinformation campaigns about the coronavirus are equipped with a wide range of instruments, ranging from conspiracy theories treating the pathogen as a biological weapon aimed at killing a significant percentage of humanity, to false information suggesting that the bleaching agent is killing the virus.

Initial observation of the information ecosystem and its dynamic changes in connection with the outbreak of the pandemic results in the formulation of the following research hypothesis.

H1: The dissemination of coronavirus disinformation relies on an information laundering theory mechanism.

False information is legitimized by public institutions, agencies, authorities, etc., considered to be credible.

H2: Disinformation techniques are changing as a result of the coronavirus pandemic.

There are tools and techniques aimed at effectively influencing the audience. Social media, in turn, is the main arena for this type of activity.

\footnotetext{
1 Director-General of the World Health Organization.
} 
Most definitions of disinformation emphasize close correlation with false information, which may include genuine news intentionally used in the wrong context to obtain a false link, fake news sites, or designed to imitate credible sources. Some studies have found that false information spreads faster and wider than real news. However, this effect depends on individual platforms (Cinelli et al., 2020). The multiplicity of definitions and approaches to the term 'disinformation' allows us to look at this process through the prism of actions aimed at erasing history, the knock of which is the lack of critical thinking or the constant reading of facts. In this sense, disinformation "softens" the ability to consciously process information (Flore et al., 2019).

Classic understandings of the term 'fake news' indicate a political, economic and often entertainment motivation, appropriately profiling the context of such information. However, in the era of a pandemic, another type of fake news is noticeable, namely, medical fake news. Examples of the impact of this type of disinformation in a pandemic context can be multiplied. According to reports by the Iranian Ministry of Health, more than 5,000 people were poisoned with methanol (Regencia, Siddiqui, \& Najjar, 2020). Information on the virucidal properties of this chemical was obtained from social media. The cited case shows that the process of generating false information mutates as quickly as the pathogen.

What makes medical fake news so common on social media? The Internet and social media in the $21^{\text {st }}$ century became a source of medical knowledge, it is on these platforms that digital natives look for knowledge on health-related topics. However, looking at this phenomenon from a slightly different perspective, this data mining allows to aggregate and use information from social media for health protection purposes. The case of Google from 2009 should be mentioned here: the data collected from queries in the Google search engine allowed, using algorithms, to create a map of the spread of H1N1 flu in the United States in real time and make it available to the CDC (Racka, 2016). It is also symptomatic that the organizations, institutions and agencies responsible for providing information on the coronavirus pandemic have just established the Internet, and especially social media, as the primary communication channel.

Social media platforms have revolutionized the existing static model of information dissemination, giving it speed, variety, volume, and streaming. The aforementioned attributes define the contemporary information ecosystem. The emergence of platforms such as Twitter, Facebook, Instagram, YouTube, resulted in a new sequence of information proliferation. As Klein (2012) notes, the so far 
well-explored theories of Jowett and O'Donnell's white propaganda and Borrowman's academic and techno-ethos (manipulation of information in cyberspace) affect the shape of modern propaganda in a digital version. The model of white propaganda shows the advisability of blurring the line between persuasion and information. As a result, a message is generated that seems to be very close to the truth. This opens the way to the information laundering theory. Klein (2012) compares the information laundering process to money laundering, with the difference, however, that the currency of the latter is information. Through the web, groups that spread certain rhetoric easily gain legitimacy for the content they propagate. Information laundering is not only about "cleaning" the content in the mainstream of information, but also focuses on the tactic of innuendo, understatement, leaving the recipient with an apparent possibility of interpretation. The scheme of "information laundering" in cyberspace is largely based on the mechanism of positioning pages in search engines, which in turn are based on algorithmic logic.

Information laundering 2.0 mechanism includes three phases: placement, layering, integration. The first stage is to prepare an appropriate narrative so as to achieve maximum impact on the audience (Korta, 2018). Disinformation campaigns grounded in the theory of information laundering are based on selected social media accounts that are able to ensure rapid dissemination of information in a way that makes it impossible to indicate the source and intention of the sender of the message (Meleshevich \& Schafer, 2018). Layering involves processing information using domains until it reaches the appearance of credibility. In this phase, accelerators in the form of online advertising, positioning, computational propaganda are used (Korta, 2018). Meleshevich and Schafer (2018) argue that the layering of disinformation campaigns takes two forms. The first is to use social media accounts to disseminate information that does not show any correlation with the author of the information. The second is based on the so-called cascading citations, i.e., retweets, reposts, shares. The last phase is integration, in which information is located in the public discourse, becoming part of knowledge (Korta, 2018). In this phase, information is received by credible sources of information or shared by real users of social media (Meleshevich \& Schafer, 2018), as opposed to the computational propaganda tools used before. The classic theory of information laundering should be combined with hate speech. A diagram of how information is given the appearance of credibility - through the statements of experts - in order to reach the mainstream of information, can be related to the wider phenomenon 
of disinformation and fake news. Today, the information laundering process takes place in cyberspace.

The outbreak of the coronavirus epidemic has become an impulse for the intensification of disinformation campaigns. Since the outbreak of the epidemic, $113^{2}$ fake news about the coronavirus has been identified in the Polish information space (Krótki przewodnik po fake newsach o koronawirusie, 2020). The cycle of proliferation of some false information in its logic follows the theory of information laundering. Institutional authentication of information is carried out by indicating the entity that introduces a given false information into public discourse.

Table 1. Selected Fake News about the Coronavirus in the Polish Information Space

\begin{tabular}{|l|l|}
\hline Fake news & An entity that authenticates information \\
\hline $\begin{array}{l}\text { Inhabitants of Silesia, the best group tested for } \\
\text { coronavirus }\end{array}$ & The Ministry of State Assets \\
\hline Polish doctors say that we do not have a coronavirus & $\begin{array}{l}\text { Provincial consultant for infectious diseases prof. } \\
\text { Simon. January information }\end{array}$ \\
\hline $\begin{array}{l}\text { German companies get } 14,000 \text { euro per month of } \\
\text { support }\end{array}$ & Provided by the MP \\
\hline $\begin{array}{l}\text { The government wants to withdraw from the } 500 \\
\text { plus }\end{array}$ & Social media \\
\hline $\begin{array}{l}\text { A new virus from China is coming (about } \\
\text { hantavirus) }\end{array}$ & $\begin{array}{l}\text { Information published by Super Express, Gazeta } \\
\text { Pomorska }\end{array}$ \\
\hline $\begin{array}{l}\text { Poczta Polska will open parcels without the } \\
\text { recipient's consent }\end{array}$ & Social media \\
\hline The European Union threatens Poland with fines & TVP INFO \\
\hline Helicopters spraying disinfectants & Social media \\
\hline $\begin{array}{l}\text { Coronavirus does not pose a threat to participants } \\
\text { of religious gatherings }\end{array}$ & Fr. T. Guz in an interview for TV Trwam \\
\hline Expired masks were distributed in the Sejm & $\begin{array}{l}\text { Statement by a member of the Coalition Parlia- } \\
\text { mentary Club of the Left }\end{array}$ \\
\hline $\begin{array}{l}\text { Poland did not let Russian Il-76s pass with medical } \\
\text { aid to Italy }\end{array}$ & Information provided by Russian Sputnik \\
\hline $\begin{array}{l}\text { During the quarantine, } 100 \text { GG antennas were } \\
\text { launched in the Tri-City }\end{array}$ & Social media \\
\hline
\end{tabular}




\begin{tabular}{|l|l|}
\hline Fake news & An entity that authenticates information \\
\hline $\begin{array}{l}\text { The Great Orchestra of Christmas Charity refused to } \\
\text { support the fight against the coronavirus }\end{array}$ & Social media \\
\hline Pets should be put down to avoid becoming infected & Social media \\
\hline $\begin{array}{l}\text { Radio RMF FM announced the closure of voivode- } \\
\text { ship borders in Poland }\end{array}$ & Website rmf-24.pl \\
\hline $\begin{array}{l}\text { Kidnapping a child from an infectious diseases } \\
\text { hospital in Warsaw }\end{array}$ & Website warszawa-info24[.]pl \\
\hline The virus can be spread using food & Social media \\
\hline $\begin{array}{l}\text { Large stocks of food should be stocked as there may } \\
\text { be a shortage }\end{array}$ & Social media \\
\hline Warsaw will be cordoned off & Social media \\
\hline $\begin{array}{l}\text { The preventive measures introduced by the Polish } \\
\text { government are in fact the introduction of the } \\
\text { "sanitary police" and the implementation of the plan } \\
\text { of "martial law plus" }\end{array}$ & Social media \\
\hline
\end{tabular}

Source: author's own elaboration based on Krótki przewodnik... (2020).

The detection of fake news in pandemic conditions is a fundamental challenge for the functioning of the information ecosystem. The spectrum of techniques for this purpose is expanded with new tools enabling quick identification and deactivation of disinformation in social media. It is a series of solutions bordering on semantics, algorithms and computational methods: artificial intelligence, NLP, machine learning, function extraction, social context modelling, sentiment analysis (Mesquita et al., 2020).

Disinformation in the analyzed aspect involves not only social media concerns but also countries - the source and victims of this type of campaign. At the beginning of March 2020, European agendas alerted us to increased Russian disinformation (European External Action Service, 2020). Fake news about the Polish side's refusal to allow Russian planes to fly through Polish airspace to deliver medical aid to Italy is one of the many examples of the Kremlin's "information policy". It is worth mentioning the joint initiatives undertaken by governments and social media to limit the spread of disinformation. WhatsApp, owned by Facebook, together with the Indian government, has launched a chatbot to ensure that the public has access to reliable information on COVID-19. This is the answer to misinformation and disinformation in India, where, according to reports from global media, Hindus were clapping loudly and ringing bells 
to protect themselves from infection (Brindha, Jayaseelan, \& Kadeswara, 2020). Another example is the decision made by Twitter, Facebook and YouTube, which resulted in the removal of posts shared by Brazilian President Jair Bolsonaro that were deemed to be misleading to Brazilian society. The example cited is an exemplification of "top-down" disinformation (Brennen et al., 2020).

In some political systems, the coronavirus becomes a tool of the political game, often also a pretext for making controversial decisions. The unprecedented global health crisis caused by the pandemic has provoked reactions from rightwing circles in many European countries, most strongly in France, Germany, and Italy. The most frequently raised demand was the introduction of stricter border controls. As noted by Colomina (2020), the right-wing discourse linking immigration with health hazards is visible in the statements of politicians such as: J. Kaczyński, M. Salvini, J. Ortega Smith. The logic of such rhetoric is based on generating and fueling the idea of an external threat. In the behavior of many countries, strong isolationist tendencies are noticeable, for example in the United States, caused by the decision of the Trump administration to unilaterally suspend travel from Europe.

Disinformation in the era of the coronavirus pandemic is nothing new, the mechanism of disinformation campaigns remains the same, although instruments are modified, profiling towards, e.g., medical fake news. It is important to identify the factors influencing the dissemination of false information.

The findings of the Pennycook et al. (2020) research team on misinformation during the COVID-19 pandemic in the United States point to factors that could be considered to enable and multiply the dissemination of false information about the pandemic. One is political orientation. The analysis showed that Republicans were less concerned about COVID-19 and less likely to share real COVID-19 content than Democrats. Another identified factor is cyberchondria, which should be understood as searching the Internet for health information that is fueled by an underlying health concern that is causing an increase in anxiety. Laato et al. (2020) prove that cyberchondria is a side effect of the COVID-19 pandemic.

Another identified factor is information overload, the results of the search for "coronavirus" in Google Trends show that over the month, there has been a significant increase in the interest in information on the Web. The peak was reached on March 8-14.

The avalanche of information growth on the Internet generates favorable conditions for conducting disinformation campaigns. In the information 


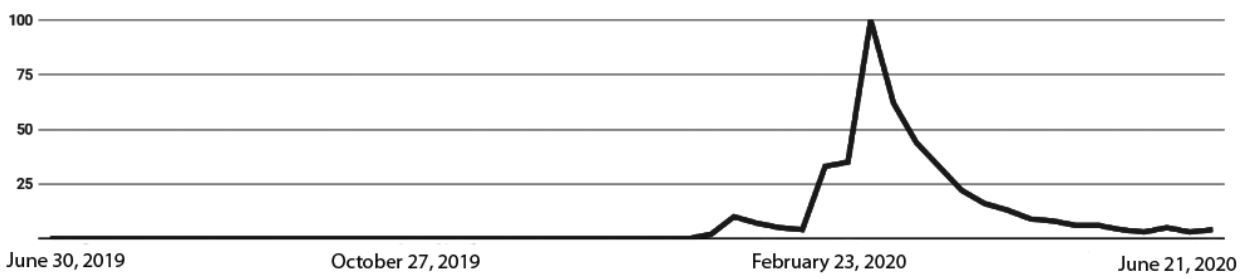

Chart 1. The Popularity of the Term 'Coronavirus' in the Google Search Engine in Poland Legend: A value of 100 is the most popular keywords. A value of 50 means that the popularity of the password was twice as low. A value of 0 indicates that there is insufficient data for the password.

Source: author's own study using the Google Trends tool.

environment dominated by rapidly emerging information, it is more difficult to verify. This process is even more difficult if false information is provided by the media and authorities. According to the World Health Organization, the coronavirus has caused not only a global pandemic, but an infodemic - global disinformation. Infodemic has a strong impact on the information ecosystem, resulting in an avalanche of false information, conspiracy theories and content that generates hate speech.

The legitimation of false information by reliable entities causes the recipients to disable the information verification mechanism. In turn, for disinformers, it most often means an effective influence. In connection with the above, it can be concluded that the information laundering model is used in disinformation campaigns around the pandemic.

For the social media disinformation pandemic, there is no "vaccine" or "cure". Therefore, it is a challenge for modern states, social media and fact-checking organizations. It also indicates the need for more efficient detection of fake news and disinformation by social media algorithms. Research on disinformation should be placed in a broad context, taking into account technological, political and social factors. 


\section{REFERENCES:}

Brennen, J.S., Simon, F.M., Howard, P.N., \& Nielsen, R.K. (2020). Types, Sources, and Claims of COVID-19 Misinformation, 1-13. Retrieved from: https://reutersinstitute. politics.ox.ac.uk/sites/default/files/2020-04/Brennen\%20-\%20COVID\%2019\%20 Misinformation\%20FINAL\%20\%283\%29.pdf.

Brindha, D., Jayaseelan, R., \& Kadeswara, S. (2020). Social Media Reigned by Information or Misinformation about COVID-19: A Phenomenological Study. SSRN Electronic Journal, 9(3), 585-602. DOI: 10.2139/ssrn.3596058.

Cinelli, M., Quattrociocchi, W., Galeazzi, A., Valensise, C.M., Brugnoli, E., Schmidt, A.L., Zola, P., Zollo, F., \& Scala, A. (2020). The COVID-19 Social Media Infodemic, 1-18. Retrieved from: https://arxiv.org/pdf/2003.05004.pdf.

Colomina, C. (2020). CORONAVIRUS: Infodemics and Disinformation, 1-3. Retrieved from: https://www.cidob.org/en/publications/publication_series/opinion/ seguridad_y_politica_mundial/coronavirus_infodemics_and_disinformation.

Cotter, C. (2020, April 23). From the "Spanish Flu" to COVID-19: Lessons from the 1918 Pandemic and First World War. Retrieved from: https://blogs.icrc.org/law-andpolicy/2020/04/23/spanish-flu-covid-19-1918-pandemic-first-world-war/.

European External Action Service (2020, April 1). EEAS Special Report Update: Short Assessment of Narratives and Disinformation around the COVID-19 Pandemic. Retrieved from: https://euvsdisinfo.eu/eeas-Special-report-update-short-assessment-of-narratives-and-disinformation-around-the-covid-19-pandemic/.

Flore, M., Balahur, A., Podavini, A., \& Verile, M. (2019). Understanding Citizens' Vulnerabilities to Disinformation and Data-Driven Propaganda. JRC Technical Reports. Luxembourg: Publications Office of the European Union. DOI: 10.2760/919835. Retrieved from: https://publications.jrc.ec.europa.eu/repository/bitstream/ JRC116009/understanding_citizens_vulnerabilities_to_disinformation.pdf.

Iran: Over 700 Dead After Drinking Alcohol to Cure Coronavirus. Retrieved from: https:// www.aljazeera.com/news/2020/4/27/iran-over-700-dead-after-drinking-alcoholto-cure-coronavirus.

Klein, A. (2012). Slipping Racism into the Mainstream: A Theory of Information Laundering. Communication Theory, 22(4), 427-448. DOI: $10.1111 / \mathrm{j} .1468-$ 2885.2012.01415.x.

Korta, S.M. (2018). Fake News, Conspiracy Theories, and Lies: An Information Laundering Model for Homeland Security [Master's Thesis]. Retrieved from: https://books. google.pl/books?id=oDFtDwAAQBAJ\&pg=PA97\&lpg=PA97\&dq=laundering+inf ormation\&source $=$ bl\&ots $=z P u y D c P X o k \& s i g=A C f U 3 U 3 H c p K 5 p U j X A X f t W K O h$ 9TFPESfsbw\&hl=pl\&sa=X\&ved=2ahUKEwiAvqrM3jpAhUGwQIHHUKvBVAQ6 $\mathrm{AEwDXoECA0QAQ} \# \mathrm{v}=$ onepage\&q=laundering\%20information \&f=false.

Krótki przewodnik po fake newsach o koronawirusie (2020). Retrieved from: https:// www.cyberdefence24.pl/krotki-przewodnik-po-aktualnych-fake-newsach-okoronawirusie. 
Laato, S., Islam, A.K.M.N., Islam, M.N., \& Whelan, E. (2020). Why Do People Share Misinformation during the COVID-19 Pandemic? 1-20. Retrieved from: https:// arxiv.org/ftp/arxiv/papers/2004/2004.09600.pdf.

Meleshevich, K., \& Schafer, B. (2018). Online Information Laundering: The Role of Social Media. Alliance for Securing Democracy, 002, 1-7. Retrieved from: https:// securingdemocracy.gmfus.org/wp-content/uploads/2018/06/InfoLaundering_finaledited.pdf.

Mesquita, C.T., Oliveira, A., Seixas, F.L., Paes, A. (2020). Infodemia, Fake News and Medicine: Science and the Quest for Truth. International Journal of Cardiovascular Sciences, 33(3), 203-205. DOI: 10.36660/ijcs.20200073.

Pennycook, G., McPhetres, J., Zhang, Y., \& Rand, D.G. (2020). Fighting COVID-19 Misinformation on Social Media: Experimental Evidence for a Scalable Accuracy Nudge Intervention, 1-24. Retrieved from: http://ide.mit.edu/sites/default/files/ publications/Covid-19\%20fake\%20news\%20ms_psyarxiv.pdf.

Racka, K. (2016). Big data - znaczenie, zastosowania i rozwiązania technologiczne. Zeszyty Naukowe PWSZ w Płocku. Nauki Ekonomiczne, 23, 311-323. 